\title{
Production of belite calcium sulfoaluminate cement using sulfur as a fuel and as a source of clinker sulfur trioxide: pilot killn trial
}

\section{Theodore Hanein}

PhD Student, School of Engineering, University of Aberdeen, Aberdeen, UK

Isabel Galan

Research Fellow, Department of Chemistry, University of Aberdeen, Aberdeen, UK

\section{Ammar Elhoweris}

PhD Student, Department of Chemistry, University of Aberdeen, Aberdeen, UK

\section{Sameer Khare}

Research Fellow, School of Engineering, University of Aberdeen, Aberdeen, UK

\section{Solon Skalamprinos}

PhD Student, Department of Chemistry, University of Aberdeen, Aberdeen, UK
Gabriel Jen

Research Fellow, School of Engineering, University of Aberdeen, Aberdeen, UK

Mark Whittaker

Research Fellow, School of Engineering, University of Aberdeen, Aberdeen, UK

\section{Mohammed S. Imbabi}

Senior Lecturer, School of Engineering, University of Aberdeen, Aberdeen, UK

Frederik P. Glasser

Chair in Chemistry, Department of Chemistry, University of Aberdeen, Aberdeen, UK

\section{Marcus N. Bannerman}

Lecturer, School of Engineering, University of Aberdeen, Aberdeen, UK (corresponding author: m.campbellbannerman@abdn.ac.uk)

A pilot-scale trial was undertaken in a $7.4 \mathrm{~m}$ kiln to demonstrate the production of belite calcium sulfoaluminate cement clinker using sulfur as a raw feed. The sulfur was introduced in its elemental form as fuel to the burner, thus partially offsetting fuel costs while providing sulfur trioxide which is incorporated in the clinker. The study demonstrates that sulfur trioxide is readily sequestered into cement clinker in a standard rotary kiln; however, some scrubbing of the exit gas may still be required. As the products of scrubbing (anhydrite or gypsum) are usually required to optimise the cement formulation, the recovered sulfur product can find an immediate use in the final cement product. This trial demonstrates the successful production of targeted belite calcium sulfoaluminate clinkers at scale using sulfur as both a fuel and sulfur trioxide source.

\section{Introduction}

Belite calcium sulfoaluminate (b-C\$A) cements are currently under rapid development and offer a number of advantages over Portland cement (Alvarez-Pinazzo et al., 2012; Chen and Juenger, 2011; Gartner, 2004; Hasanbeigi et al., 2012; Juenger et al., 2011; Li et al., 2007). These b-C\$A cements are an attractive alternative to Portland cement due to the lower carbon dioxide $\left(\mathrm{CO}_{2}\right)$ emissions associated with their production. The reduction in carbon dioxide is achieved through a lower clinkering temperature and a reduced lime factor relative to Portland cement (Hanein et al., 2016). A key characteristic of b-C $\$ A$ cements is that they contain ye'elimite $\left(\mathrm{C}_{4} \mathrm{~A}_{3} \$\right)$ (the cement clinker phases used in this paper are written in cement notation, as shown in Table 1). The sulfur necessary to form phases such as ye'elimite is conventionally introduced into the raw feed as gypsum and/or anhydrite; however, further economies of production can be achieved by the partial substitution of carbon-based fuels by sulfur (Hanein et al., 2016). Sulfur is naturally available in 'sour' fuels and also in its elemental form as a by-product of the desulfurisation of 'sour' oil and natural gas. Although using calcium sulfate $\left(\mathrm{CaSO}_{4}\right)$ (as opposed to sulfur) as a raw material provides a lower raw material 'carbon footprint', the generation of calcium sulfate (when created as a by-product of the energy industry) typically requires the de-carbonation of limestone and thus it may have some inherent carbon dioxide emissions associated with its production; nonetheless, utilising sulfur products to form reactive cement clinker phases is still highly effective in significantly reducing the environmental burden caused by the production of cement due to the high heat of combustion of sulfur. A recent study by the authors has demonstrated that the carbon dioxide emitted by calcination of the raw material is increased by up to $15 \%$ over using calcium sulfate as a raw feed; however, more than $50 \%$ of the theoretical heat of clinkerisation can be supplied by the sulfur combustion for high-ye'elimite clinkers 
Advances in Cement Research

Volume 28 Issue 10
Production of belite calcium

sulfoaluminate cement using sulfur

as a fuel and as a source of clinker

sulfur trioxide: pilot kiln trial

Hanein, Galan, Elhoweris et al.

\begin{tabular}{ll}
\hline Oxide & Notation \\
\hline Calcium oxide $(\mathrm{CaO})$ & $\mathrm{C}$ \\
Silicon dioxide $\left(\mathrm{SiO}_{2}\right)$ & $\mathrm{S}$ \\
Sulfur trioxide $\left(\mathrm{SO}_{3}\right)$ & $\$$ \\
Iron oxide $\left(\mathrm{Fe}_{2} \mathrm{O}_{3}\right)$ & $\mathrm{F}$ \\
Titanium dioxide $\left(\mathrm{TiO}_{2}\right)$ & $\mathrm{T}$ \\
Aluminium oxide $\left(\mathrm{Al}_{2} \mathrm{O}_{3}\right)$ & $\mathrm{A}$ \\
Magnesium oxide $(\mathrm{MgO})$ & $\mathrm{M}$ \\
Potassium oxide $\left(\mathrm{K}_{2} \mathrm{O}\right)$ & $\mathrm{K}$ \\
Phosphorus pentoxide $\left(\mathrm{P}_{2} \mathrm{O}_{5}\right)$ & $\mathrm{P}$
\end{tabular}

Table 1. Cement notation used in this work

(Hanein et al., 2016). Even for moderately efficient kilns this represents a significant reduction of carbon dioxide emissions, once the carbon dioxide released by the kiln burner is included in the calculations.

Laboratory experiments and thermodynamic modelling have already demonstrated that sulfur dioxide $\left(\mathrm{SO}_{2}\right.$, a combustion product of sulfur) and oxygen $\left(\mathrm{O}_{2}\right)$ are readily transferred from the gas phase to $\mathrm{C}-\mathrm{S}-\mathrm{A}-\mathrm{F}$ solid oxides to form ye'elimite (Galan et al., 2014; Galan et al. 2016, Advances in clinkering technology of calcium sulfoaluminate cements, unpublished manuscript, University of Aberdeen; Hanein et al., 2015a; Strigac and Majling, 1997). These experiments have demonstrated significant sulfur trioxide $\left(\mathrm{SO}_{3}\right)$ mass gains in clinker phases as opposed to the more typical mass losses experienced under conventional operating conditions. In addition, the partial pressure of sulfur dioxide in the atmosphere is found to strongly influence the stable clinker phase composition. These observations indicate that control of the kiln atmosphere and consideration of gas-solid reactions in clinker manufacture are essential to allow greater freedom in designing b-C $\$$ A clinkers with optimised clinker compositions.

In standard clinker production methods using a rotary kiln, a significant loss of sulfur may occur at clinkering temperatures via the evolution of $\mathrm{SO}_{x}$ gas that is swept from the kiln. A novel process technology (Galan et al., 2014; Galan et al., 2016, Advances in clinkering technology of calcium sulfoaluminate cements, unpublished manuscript, University of Aberdeen; Imbabi et al., 2014) that inhibits sulfur loss and even allows sulfur to be used as a fuel/energy source partially replacing hydrocarbon fuel and lowering specific carbon dioxide releases is reported here. The paper also presents results of a pilot-scale trial to produce b-C\$A clinkers in which all the sulfur embodied in the clinker was transferred from the kiln atmosphere to the clinker product via solid-gas reactions.

\section{Pilot kiln trial mix design}

In order to closely approximate a full-scale industrial process, the raw feed used in the trial reported here was formulated from materials normally utilised in the cement industry (i.e. clay, limestone and bauxite sourced from commercial suppliers). The average particle size of the raw materials was $\approx 0.04 \mathrm{~mm}$. To design the raw mix using stoichiometric calculations, quantification of the oxide composition of the raw materials was required. For the clay and bauxite, x-ray fluorescence (XRF) analysis was carried out on a PANalytical PW2402 wavelengthdispersive sequential $\mathrm{x}$-ray spectrometer. The oxide composition of the limestone was provided by the producer. Major oxides, shown in Table 2, were measured on fused discs of sample material in a borate flux matrix. A loss-on-ignition test was also carried out on each raw material by heating a sample at $1000^{\circ} \mathrm{C}$ for $15 \mathrm{~min}$. The mass losses of the limestone, bauxite and clay were measured to be $43.97 \%, 13.3 \%$ and $13.8 \%$, respectively. The balance of the material masses reported in Table 2 are consistent with the masses lost on ignition.

To provide a basis for calculations, the ferrite composition was assumed to be $\mathrm{C}_{6} \mathrm{~A}_{2} \mathrm{~F}$ due to the high alumina to iron ratio of the raw feed $(\approx 10: 1$ by mass); this assumption is based on phase composition trends observed by Touzo et al. (2013). The designed raw-meal mix contained, by weight, $64 \cdot 4 \%$ limestone, $8.9 \%$ bauxite and $26.7 \%$ clay. It should be noted that no sulfur-containing phases were added to the batch. The formulation was stoichiometrically optimised for a target clinker

\begin{tabular}{|c|c|c|c|c|}
\hline & Limestone & Bauxite & Clay & Raw mix \\
\hline Calcium oxide (CaO): wt\% & $55 \cdot 7$ & $0 \cdot 16$ & 0.87 & $36 \cdot 12$ \\
\hline Aluminium oxide $\left(\mathrm{Al}_{2} \mathrm{O}_{3}\right)$ : wt\% & - & $69 \cdot 32$ & $38 \cdot 18$ & $16 \cdot 36$ \\
\hline Silicon dioxide $\left(\mathrm{SiO}_{2}\right):$ wt\% & $0 \cdot 1$ & $11 \cdot 52$ & $39 \cdot 24$ & $11 \cdot 57$ \\
\hline Iron oxide $\left(\mathrm{Fe}_{2} \mathrm{O}_{3}\right)$ : wt $\%$ & 0.009 & $1 \cdot 21$ & $5 \cdot 98$ & $1 \cdot 71$ \\
\hline Titanium dioxide $\left(\mathrm{TiO}_{2}\right):$ wt\% & - & $3 \cdot 409$ & $1 \cdot 773$ & $0 \cdot 78$ \\
\hline Magnesium oxide (MgO): wt\% & 0.26 & 0.0 & 0.06 & $0 \cdot 18$ \\
\hline Potassium oxide $\left(\mathrm{K}_{2} \mathrm{O}\right)$ : wt $\%$ & - & $0 \cdot 455$ & 0.624 & 0.21 \\
\hline Phosphorus pentoxide $\left(\mathrm{P}_{2} \mathrm{O}_{5}\right)$ : wt\% & - & 0.081 & - & 0.03 \\
\hline
\end{tabular}

Table 2. XRF analysis of raw materials used in the pilot kiln trial 
Advances in Cement Research

Volume 28 Issue 10
Production of belite calcium

sulfoaluminate cement using sulfur

as a fuel and as a source of clinker

sulfur trioxide: pilot kiln trial

Hanein, Galan, Elhoweris et al. consisting of three major phases $\left(\mathrm{C}_{4} \mathrm{~A}_{3} \$, \mathrm{C}_{2} \mathrm{~S}, \mathrm{C}_{6} \mathrm{~A}_{2} \mathrm{~F}\right)$ using the assumptions that:

- alkali oxides form alkali sulfates

- titanium dioxide $\left(\mathrm{TiO}_{2}\right)$ reacts to form perovskite $\left(\mathrm{CaTiO}_{3}\right)$

- ferric oxide $\left(\mathrm{Fe}_{2} \mathrm{O}_{3}\right)$ forms ferrite only

- silicon dioxide $\left(\mathrm{SiO}_{2}\right)$ forms belite $\left(\mathrm{C}_{2} \mathrm{~S}\right)$

- the remaining aluminium oxide $\left(\mathrm{Al}_{2} \mathrm{O}_{3}\right)$ will form ye'elimite $\left(\mathrm{Ca}_{4} \mathrm{Al}_{6} \mathrm{SO}_{16}\right)$.

Magnesium oxide $(\mathrm{MgO})$ and phosphorus pentoxide $\left(\mathrm{P}_{2} \mathrm{O}_{5}\right)$ were unassigned. Initially, the clinker composition chosen for the trial was targeted at a clinker with $40 \% \mathrm{C}_{4} \mathrm{~A}_{3} \$, 55 \% \mathrm{C}_{2} \mathrm{~S}$ and $5 \% \mathrm{C}_{6} \mathrm{~A}_{2} \mathrm{~F}$ by weight. However, due to the limitations on stoichiometry arising from the composition of the raw materials, the closest attainable match was a clinker containing $40 \% \mathrm{C}_{4} \mathrm{~A}_{3} \$, 47 \% \mathrm{C}_{2} \mathrm{~S}$ and $10 \cdot 6 \% \mathrm{C}_{6} \mathrm{~A}_{2} \mathrm{~F}$ by weight.

\section{Pilot kiln design and operating conditions}

The pilot kiln trial was undertaken at the IBU-tec facility in Weimar, Germany. Elemental solid sulfur was introduced to the kiln via the burner, providing additional combustion energy as it oxidised. Prior to the start of the trial, the raw materials were mixed in a rotating drum mixer (Figure $1(\mathrm{a})$ ) for $\approx 10 \mathrm{~min}$. The raw materials were in powder form to facilitate subsequent sulfur dioxide uptake; therefore, to reduce dust losses in the kiln, $5 \mathrm{~kg}$ of water was added to each $80 \mathrm{~kg}$ of solids. The final raw meal fed into the kiln is shown in Figure 1(b).

The pilot kiln described in Table 3 was used to test the clinkering process. The inside of the kiln was lined with $5 \mathrm{~cm}$ thick refractory cement to limit heat loss and to provide a smooth interior lining for solid transport. Table 4 provides the properties of the cement lining. The kiln configuration consisted of the kiln tube, a gravimetric screw feeder to transport raw material into the kiln tube, a cyclonic kiln dust separator, a fabric dust/bag filter, an exhaust gas extractor fan, a burner (BIO 125HB 100/100 from Krom-Schröder) and a gravimetric sulfur feeder.
To enable the process to rapidly reach steady state, the kiln was first brought up to operating temperature prior to starting the raw material feed. The fuel used was a combination of $99.9 \%$ pure commercial sulfur in powder form and natural gas

\begin{tabular}{ll}
\hline Length & $7 \cdot 4 \mathrm{~m}$ \\
Inner diameter & $0.3 \mathrm{~m}$ \\
Refractory thickness & $5 \mathrm{~cm}$ \\
Steel thickness & $5 \mathrm{~mm}$ \\
Inclination & $1^{\circ}$ \\
rpm & $2 \cdot 0$ \\
Operating configuration & Counter current flow \\
Heating method & Directly heated \\
Fuels & Natural gas and sulfur powder \\
Sulfur feed & Gravimetric (screw feeder) \\
Natural gas feeding system & Volumetric \\
Temperature control & Optical pyrometry and \\
& thermocouples
\end{tabular}

Table 3. Properties of the pilot kiln

\section{Composition \\ $57 \cdot 0 \%$ wt $\mathrm{Al}_{2} \mathrm{O}_{3}$ \\ $38.0 \%$ wt $\mathrm{SiO}_{2}$ \\ $2 \cdot 3 \%$ wt $\mathrm{CaO}$ \\ $1 \cdot 1 \%$ wt $\mathrm{Fe}_{2} \mathrm{O}_{3}$ \\ Open porosity \\ $17 \%\left(T=800^{\circ} \mathrm{C}\right)$ \\ Density \\ $2 \cdot 5 \mathrm{~g} / \mathrm{cm}^{3}\left(T=110^{\circ} \mathrm{C}\right)$ \\ $2.45 \mathrm{~g} / \mathrm{cm}^{3}\left(T=800^{\circ} \mathrm{C}\right)$ \\ Thermal conductivity, $K$
$1.61 \mathrm{Wm}^{-1} \mathrm{~K}^{-1}\left(T=800^{\circ} \mathrm{C}\right)$
$1.62 \mathrm{Wm}^{-1} \mathrm{~K}^{-1}\left(T=1200^{\circ} \mathrm{C}\right)$
$1.71 \mathrm{Wm}^{-1} \mathrm{~K}^{-1}\left(T=1600^{\circ} \mathrm{C}\right)$

Table 4. Properties of the refractory material used as kiln lining

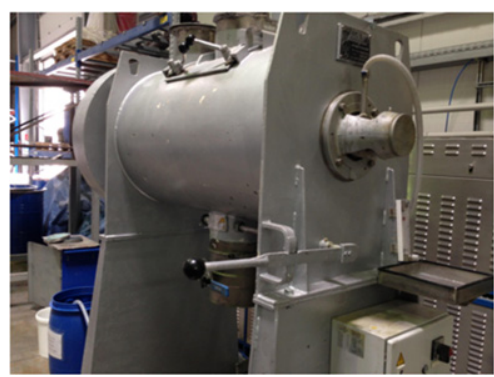

(a)

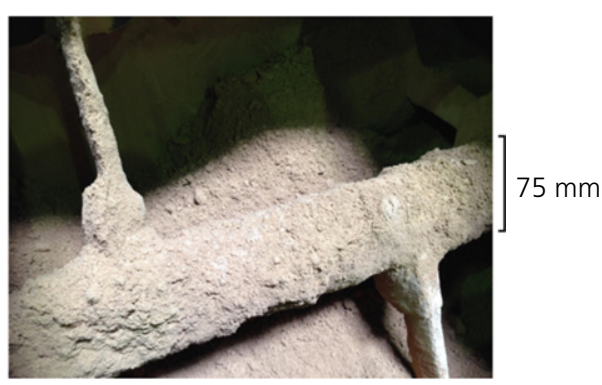

(b)

Figure 1. (a) The mixer used in the pilot-scale trial to mix the raw materials: the drum accepts $\sim 80 \mathrm{~kg}$ of powder. (b) The mixed raw meal to which water had been added 
(density at $\mathrm{STP}=0.733 \mathrm{~kg} / \mathrm{m}^{3}$ ); its chemical composition is given in Table 5. The exhaust pipe was equipped with a scrubbing system (BicarTEC) to scrub $\mathrm{SO}_{x}$ emissions. The selected absorbent for the scrubbing system was sodium bicarbonate due to its proven $\mathrm{SO}_{x}$-absorbing properties, although it is envisioned that standard calcium oxide based scrubbers may be used in full-scale production to provide gypsum (or anhydrite depending on whether a wet or dry scrubbing process is

\section{Component}

\section{Methane $\left(\mathrm{CH}_{4}\right)$}

Ethane $\left(\mathrm{C}_{2} \mathrm{H}_{6}\right)$

Nitrogen $\left(\mathrm{N}_{2}\right)$

Propane $\left(\mathrm{C}_{3} \mathrm{H}_{8}\right)$

Carbon dioxide $\left(\mathrm{CO}_{2}\right)$

Iso-butane (i- $\left.\mathrm{C}_{4} \mathrm{H}_{10}\right)$

Normal butane $\left(\mathrm{n}-\mathrm{C}_{4} \mathrm{H}_{10}\right)$

Iso-pentane $\left(\mathrm{i}-\mathrm{C}_{5} \mathrm{H}_{12}\right)$

Normal pentane $\left(\mathrm{n}-\mathrm{C}_{5} \mathrm{H}_{12}\right)$

Hydrocarbons ( $\mathrm{C}_{6}$ and higher)

Sulfur (S)

Hydrogen sulfide $\left(\mathrm{H}_{2} \mathrm{~S}\right)$

Table 5. Chemical composition of the natural gas fuel chosen) for subsequent inter-grinding with clinker or for other commercial uses.

A process flow diagram of the kiln configuration described is given in Figure 2. The $\mathrm{SO}_{x}$ absorbent was injected into the exit-gas stream and collected on a bag filter where it is assumed that the majority of the scrubbing action occurs. Two gas analysers were installed - one at the kiln raw-feed inlet, before the scrubber, to analyse and control the kiln atmosphere, and the second after the scrubbing system to monitor $\mathrm{SO}_{x}$ discharges to the atmosphere.

As predicted by thermodynamic modelling and observed experimentally (Galan et al. 2016, unpublished; Hanein et al., 2015a, 2015b), the equilibrium phase composition obtained in b-C $\$ A$ clinker is dependent on the composition of the kiln atmosphere, specifically on the temperature and the partial pressures of sulfur dioxide and oxygen. A simple idealgas/incompressible stoichiometric solid thermodynamic model, as described by (Hanein et al., 2015b), was used to optimise the required kiln atmospheric conditions and temperatures to produce the desired clinker phases. The thermodynamic data used for ye'elimite were derived previously by Hanein et al. (2015a). Due to the difficulty in controlling the temperature in the kiln, the thermodynamic model was used to calculate kiln atmospheres where the target clinker compositions were in equilibrium across the temperature range

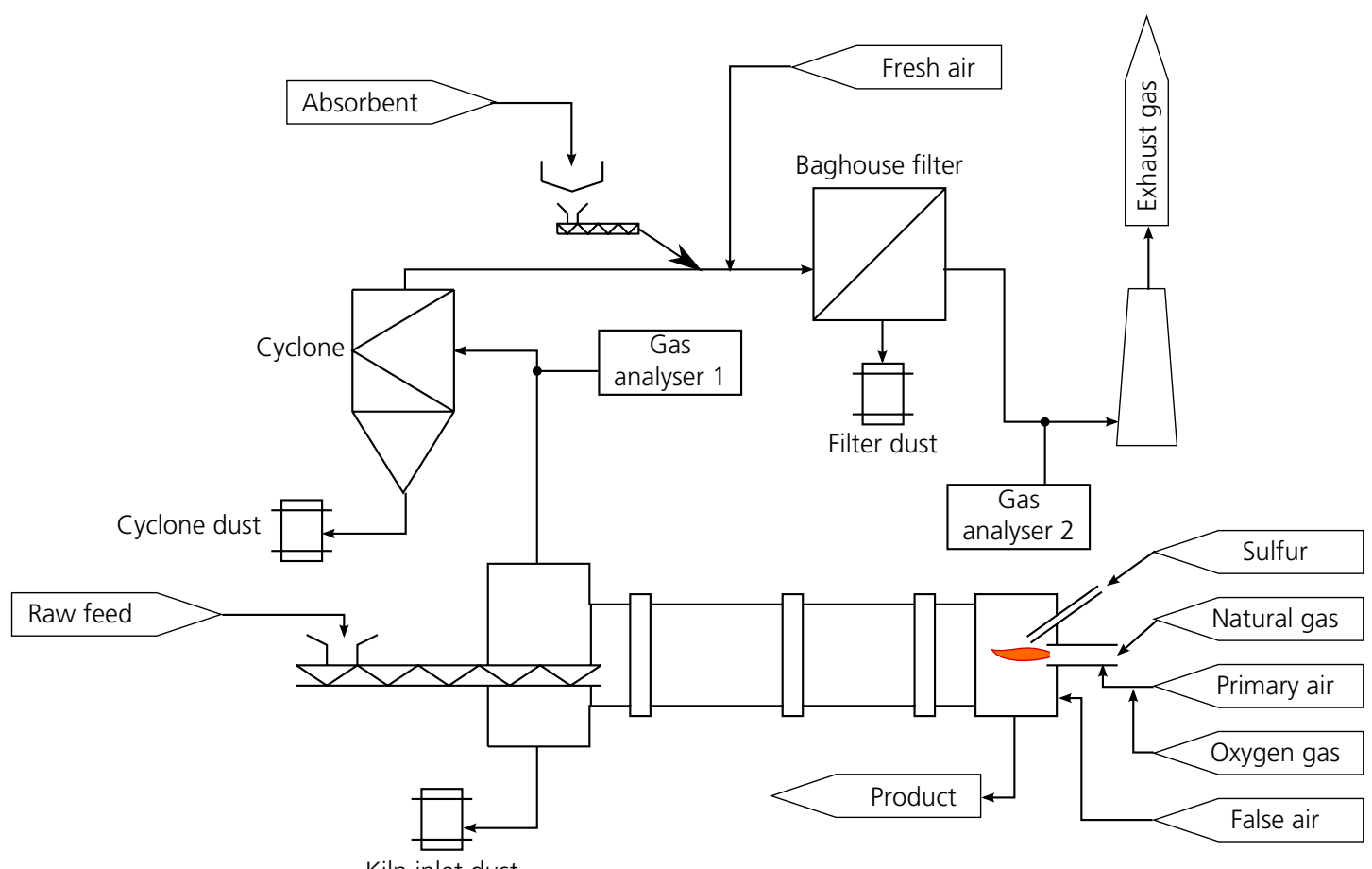

Figure 2. Kiln configuration process flow diagram for the pilot-

scale trial 
$1200^{\circ} \mathrm{C}-1300^{\circ} \mathrm{C}$. Three main regions of phase development were encountered:

- at high partial pressures of sulfur dioxide and oxygen, calcium sulfate and gehlenite $\left(\mathrm{C}_{2} \mathrm{AS}\right)$ are in equilibrium

- at low partial pressures, sulfur losses will occur and the formation of calcium aluminates is predicted

a at optimised partial pressures of sulfur dioxide, belite and ye'elimite are in equilibrium.

For the target clinkers at a fixed oxygen partial pressure of $7 \cdot 2 \%$ (imposed by the excess oxygen required to reach the target temperatures in the pilot kiln), the calculated minimum and maximum sulfur dioxide partial pressures required for ye'elimite and belite equilibrium across the temperature range $1200^{\circ} \mathrm{C}-1300^{\circ} \mathrm{C}$ were between $0.007 \%$ and $0.62 \%$ sulfur dioxide, respectively. Figure 3 provides an illustration of the dependence of b-C\$A clinker formation on the sulfur dioxide atmospheric pressure. In Figure 3, the oxygen partial pressure is set at $7 \cdot 2 \%(\mathrm{v} / \mathrm{v})$ atm and the temperature is set at $1260^{\circ} \mathrm{C}$; therefore, Figure 3 is only one example of a specific scenario that depicts the dependence of b-C\$A clinker stability on atmospheric pressures. However, when considering the entire process, various factors must be considered, such as oxygen pressure changes, temperature changes, the appropriate quantities and the possible formation of other phases (e.g. ternesite) and/or phase combinations. The selected operating sulfur

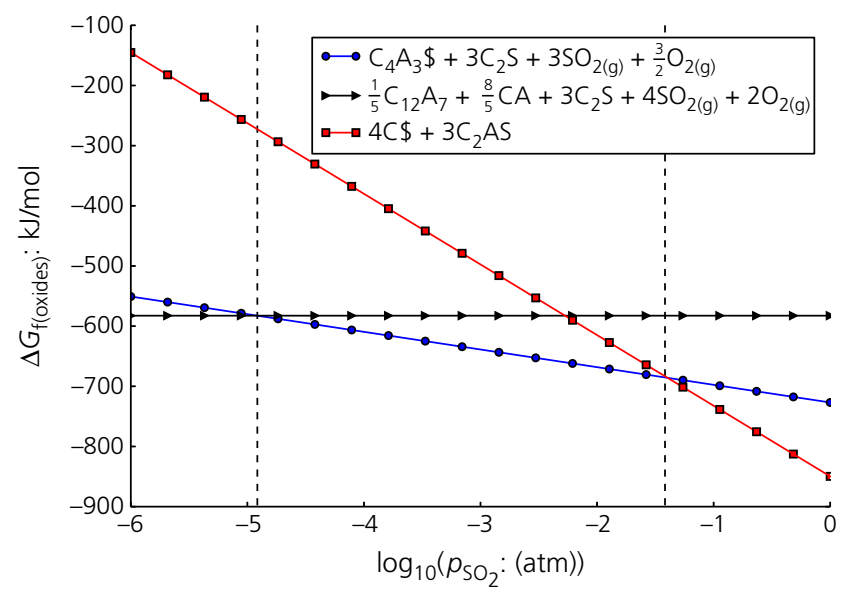

Figure 3. Plot of Gibbs free energy $\left(\Delta G_{f}\right)$ as a function of sulfur dioxide partial pressure $\left(p_{\mathrm{SO}_{2}}\right)$. The oxygen partial pressure is set at $7 \cdot 2 \%(\mathrm{v} / \mathrm{V})$ atm and the temperature is set at $1260^{\circ} \mathrm{C}$. The plot is an illustration of the dependence of C $\$ A$ clinker formation on the atmospheric pressures. The vertical dashed lines represent the sulfur dioxide upper and lower stability limits, calculated at $1260^{\circ} \mathrm{C}$, over which the pair belite and ye'elimite coexist under the specified conditions (oxygen and sulfur dioxide assumed to be in excess) which are, in this scenario, 3.8\% and 0.001\% atm sulfur dioxide, respectively dioxide partial pressure was close to the upper limit in this trial in order to promote solid-gas reactions. Due to the limitations of the thermodynamic model, it was assumed that all the iron oxide will exist as $\mathrm{C}_{6} \mathrm{~A}_{2} \mathrm{~F}$; the ferrite phase was not considered as part of the thermodynamic model.

Table 6 shows the average steady-state operating conditions of the kiln during the trial. The kiln design was not optimised for this trial, and it lacks standard heat-recovery equipment such as a preheater and clinker cooler. As a result, its thermal efficiency was approximately 3-4\% whereas industrial kilns are closer to $40-60 \%$ (Peray and Waddell, 1986). To achieve the target clinkering temperature of $1250-1275^{\circ} \mathrm{C}$, additional oxygen needed to be injected into the burner. As large gas flow rates were required to offset heat losses, it was necessary to use approximately six times the minimum required stoichiometric sulfur flow rate to produce the necessary sulfur dioxide partial pressure in the kiln atmosphere; however, with higher efficiency kilns, close to the stoichiometric sulfur burn rate is feasible. Cooling of the clinker was not controlled and the clinker was collected in a storage box located under the burner, which was emptied at irregular intervals. As the production rate was low $(\approx 5 \mathrm{~kg} / \mathrm{h}$ ), cooling was assumed to be rapid. The gas analyser readings during the trial indicated large fluctuations in sulfur dioxide concentration in the kiln during production (see Table 6). This was due to the use of a gravimetric screw feeder for the fine-powdered sulfur supply, which regularly became blocked and led to a strongly fluctuating supply to the kiln burner. Despite this, the successful production of b-C\$A clinker demonstrates the robustness of the process to

\begin{tabular}{ll}
\hline Natural gas flow rate & $21 \cdot 5 \pm 0 \cdot 3 \mathrm{~m}^{3} / \mathrm{h}$ \\
Oxygen flow rate & $3 \cdot 8 \pm 0 \cdot 2 \mathrm{~m}^{3} / \mathrm{h}$ \\
Trial time & $20 \mathrm{~h}$ \\
Clinkering zone temperature (optical & $1261 \pm 13^{\circ} \mathrm{C}$ \\
$\quad$ pyrometry (Keller MSR Optix S)) & \\
Sulfur feed rate & $2 \cdot 4 \mathrm{~kg} / \mathrm{h}$ \\
Raw-meal feed rate (wet) & $27 \mathrm{~kg} / \mathrm{h}$ \\
Raw-meal feed rate (dry) & $25 \cdot 4 \mathrm{~kg} / \mathrm{h}$ \\
Primary air & $177 \pm 7 \mathrm{~m}^{3} / \mathrm{h}$ \\
Residence time & $2 \cdot 5 \mathrm{~h}$ \\
rpm & $2 \cdot 0$ \\
Raw-meal bulk density (dry) & $0 \cdot 95 \mathrm{~g} / \mathrm{cm}^{3}$ \\
Sulfur dioxide partial pressure (burner exit) & $0 \cdot 6 \% \mathrm{~V}$ \\
Sulfur dioxide partial pressure (kiln inlet) & $0 \cdot 42 \pm 0 \cdot 1 \% \mathrm{v}$ \\
Oxygen partial pressure (kiln inlet) $_{\text {Carbon dioxide partial pressure (kiln inlet) }}$ & $7 \cdot 2 \pm 1 \cdot 2 \% \mathrm{v}$ \\
False air $^{\mathrm{a}}$ & $8 \cdot 4 \pm 0 \cdot 5 \% \mathrm{~V}$ \\
& $100 \mathrm{~m}^{3} / \mathrm{h}$
\end{tabular}

aValue calculated, not directly measured

Table 6. Average operating conditions within the kiln during the trial 
Advances in Cement Research Volume 28 Issue 10
Production of belite calcium

sulfoaluminate cement using sulfur

as a fuel and as a source of clinker

sulfur trioxide: pilot kiln trial

Hanein, Galan, Elhoweris et al. fluctuations in operating conditions. Figure 4 shows images of the produced clinker and the raw material.

\section{Results and discussion}

To quantitatively characterise the produced clinkers, four x-ray diffraction (XRD) analyses were performed and interpreted using Rietveld refinement. Three XRD analyses were of spot samples taken at 6,13 and $20 \mathrm{~h}$ into the trial. The fourth XRD analysis was carried out on a mixture of the total clinker excluding the first $3 \mathrm{~h}$ of production. The initial production was discarded as the kiln required a significant time to reach 'steady-state' operation (i.e. the calculated kiln residence time was $\approx 2.5 \mathrm{~h}$ thus production over the early residence time was discarded). XRD patterns were collected using a Philips Empyrean diffractometer in the Bragg-Brentano geometry. The diffractometer was operated at $45 \mathrm{kV}$ and $40 \mathrm{~mA}$ and was

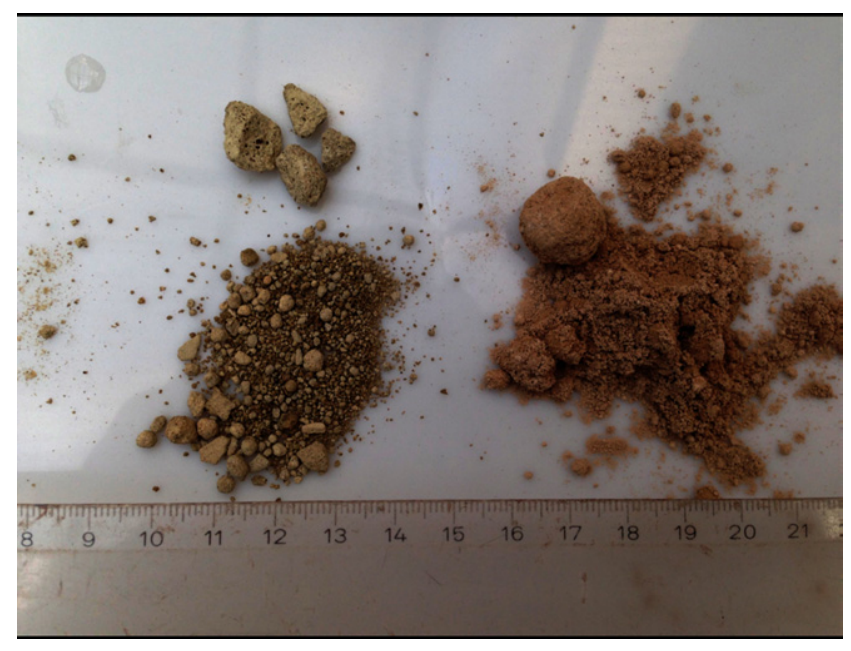

(a)

(b)

Figure 4. Produced clinker (a) and raw material (b); the scale divisions on the rule are in centimetres equipped with a $\mathrm{Cu} \mathrm{K}-\alpha$ X-ray source, a Ge monochromator and a PIXcellD detector. For analysis, each clinker was ground to a fine powder and back-loaded into the sample holders. Each pattern was measured from $5^{\circ}$ to $65^{\circ} 2 \theta$ with a step size of $0 \cdot 026^{\circ}$. The stage was set to rotate at a revolution time of $4 \mathrm{~s}$ to improve counting statistics. The Rietveld refinements were carried out using GSAS software (Larson and Von Dreele, 2004) and the crystal structures of the phases encountered were taken from various sources as follows: orthorhombic ye'elimite (Cuesta et al., 2013), cubic ye'elimite (Cuesta et al., 2014), belite (Mumme et al., 1995), ferrite (Colville and Geller, 1971), gehlenite (Louisnathan, 1971), anhydrite (Kirfel and Will, 1980), ternesite (Irran et al., 1997) and perovskite (Sasaki et al., 1987). The peaks were fitted using a pseudo-Voigt profile function (Thompson et al., 1987) with an asymmetry correction (Finger et al., 1994) included. The backgrounds were automatically fitted using a linear interpolation function. A March-Dollase ellipsoidal preferred orientation correction algorithm (Dollase, 1986) was used when the preferred orientation parameter needed refinement. Overall, all refinements were deemed satisfactory with weighted-profile $\mathrm{R}$ factor $(\mathrm{wR}$ ) values in the range $4-6 \%$. The final phase characterisation of the clinkers is given in Table 7. In order to validate the Rietveld measurements, XRF analysis of the clinker was also performed using the same procedure for the XRF analysis, as shown in Table 2. The Rietveld measurements were validated by back-calculating the oxide content from the Rietveld measurements and comparing them with the XRF analysis of the raw material and produced clinker (see Table 8). The iron oxide analysis showed the greatest deviation in the comparison; this may be due to the small amounts and crystal size effects. To further validate the sulfur content of the clinkers, the procedure described in section 4.4.2 of EN 196-2 (BSI, 2013) was used to determine the clinker sulfur trioxide content. The total sulfur trioxide content was calculated to be $9 \cdot 8 \% \mathrm{wt}$, compared with the $10 \cdot 6 \%$ wt derived from the Rietveld results, thus partially validating the quantitative aspects of the sulfur analysis.

\begin{tabular}{|c|c|c|c|c|c|c|c|}
\hline Elapsed time & $\mathrm{C}_{4} \mathrm{~A}_{3} \$(\mathrm{c}+0)^{\mathrm{a}}$ & $\mathrm{C}_{2} \mathrm{~S}\left(\beta+\alpha_{H}^{\prime}\right)^{\mathrm{b}}$ & $C \$$ & $\mathrm{C}_{2} \mathrm{AS}$ & $\mathrm{C}_{4} \mathrm{AF}$ & Others $(\leq 2 \%)^{c}$ & wRp \\
\hline $20 \mathrm{~h}$ & $14+24$ & $26+11$ & 17 & 2 & 2 & 4 & $5 \cdot 19$ \\
\hline $13 \mathrm{~h}$ & $7+27$ & $25+23$ & 7 & 4 & 3 & 4 & 6.09 \\
\hline $6 \mathrm{~h}$ & $16+25$ & $34+8$ & 11 & 3 & 1 & 2 & $5 \cdot 2$ \\
\hline Average & $12+25$ & $28+14$ & 11 & 3 & 2 & 3 & - \\
\hline $\operatorname{Mix}^{d}$ & $12+24$ & $28+15$ & 10 & 4 & 2 & 5 & $4 \cdot 65$ \\
\hline Target & 40 & 47 & - & - & $10 \cdot 6\left(\mathrm{C}_{6} \mathrm{~A}_{2} \mathrm{~F}\right)$ & $2 \cdot 4$ & - \\
\hline
\end{tabular}

${ }^{a} \mathrm{C}$ and o represent the cubic and orthorhombic polymorphs, respectively

${ }^{\mathrm{b}} \beta$ and $\alpha_{H}^{\prime}$ indicate components matching the XRD patterns for beta and high-temperature alpha prime belite

'Others refers to phases that are detected but the quantity of which is below $2 \%$ (lower than the possible error of the measurements); these include perovskite, ternesite and free lime

${ }^{\mathrm{d}}$ Mix corresponds to a mixture of the total produced clinker excluding the first $3 \mathrm{~h}$ of production

Table 7. XRD analysis of produced b-C \$A clinkers (\%wt) 


\begin{tabular}{lccc}
\hline & $\begin{array}{c}\text { XRF } \\
\text { clinker }^{\text {a }}\end{array}$ & $\begin{array}{c}\text { XRF raw } \\
\text { meal }\end{array}$ & $\begin{array}{c}\text { Quantitative XRD } \\
\text { calculations (mix) }\end{array}$ \\
\hline Calcium oxide (C) & $55 \cdot 1$ & $54 \cdot 3$ & $57 \cdot 4$ \\
Aluminium oxide (A) & $24 \cdot 1$ & $24 \cdot 6$ & $22 \cdot 6$ \\
Silicon dioxide (S) & $17 \cdot 4$ & $17 \cdot 4$ & 18 \\
Iron oxide (F) & $2 \cdot 3$ & $2 \cdot 6$ & $0 \cdot 7$ \\
Titanium dioxide (T) & $1 \cdot 1$ & $1 \cdot 2$ & $1 \cdot 3$ \\
& & & \\
\hline
\end{tabular}

aThe complete oxide composition of the produced clinker was: $C=48.28 \%, \quad A=21.09 \%, \quad S=15.25 \%, \quad \$=9.82 \%$, $\mathrm{M}=0.01 \%, \mathrm{~T}=0.96 \%, \mathrm{~F}=2.01 \%, \mathrm{~K}=0.23 \%$ and $\mathrm{P}=0.03 \%$

Table 8. Comparison of normalised oxide compositions of the produced clinker, raw meal and XRD Rietveld calculations (\%wt)

\begin{tabular}{lrr}
\hline Sieve size: $\mathrm{mm}$ & Mass retained: $\mathrm{g}$ & Mass retained: \%wt \\
\hline $35 \cdot 7$ & $0 \cdot 00$ & $0 \cdot 0$ \\
$10 \cdot 0$ & $102 \cdot 88$ & $7 \cdot 4$ \\
$5 \cdot 00$ & $170 \cdot 81$ & $12 \cdot 2$ \\
$2 \cdot 36$ & $136 \cdot 00$ & $9 \cdot 7$ \\
$1 \cdot 18$ & $207 \cdot 36$ & $14 \cdot 8$ \\
$0 \cdot 6$ & $317 \cdot 45$ & $22 \cdot 7$ \\
$0 \cdot 3$ & $245 \cdot 34$ & $17 \cdot 5$ \\
$0 \cdot 15$ & $78 \cdot 25$ & $5 \cdot 6$ \\
$<0 \cdot 15$ & $141 \cdot 23$ & $10 \cdot 1$ \\
Total & $1399 \cdot 32$ & $100 \cdot 0$
\end{tabular}

Table 9. Particle size distribution of the produced clinkers

The produced clinker was close to the predicted phase composition, which demonstrates the successful transfer of sulfur from the gas phase to produce a controlled composition of b-C\$A clinker. A second validation of the sulfur absorption was observed in the difference in sulfur dioxide concentration between calculated amounts exiting the burner and the amount measured in the kiln off-gas $(0 \cdot 18$ mole $\%)$, which is equivalent to the stoichiometric minimum amount required to achieve the mixed clinker outputs (given in Table 7) from the specified raw materials. In practice, only around $30 \%$ of the expected clinker output mass was obtained due to large dust losses. This was unavoidable due to the small diameter of the kiln and the high gas velocities resulting from the low thermal efficiency. The final clinker oxide chemical analysis was also relatively close to the initial raw mix, and therefore the chemical composition of the dust recovered with the bag filter was not analysed. The clinker dust may well have a different mineralogical composition to the produced clinker; however, there was no evidence that the dust loss had any effect on the produced clinker.
The presence of $\mathrm{C} \$$ and $\mathrm{C}_{2} \mathrm{AS}$ must be explained, as the thermodynamic calculations indicate that the pair are unstable at $1200^{\circ} \mathrm{C}-1300^{\circ} \mathrm{C}$ under the kiln atmospheric conditions. The authors believe that the main reason for their presence is due to the combined temperature and pressure fluctuations (see Table 6) in the kiln, which affected the stable clinker phase composition (as explained earlier). This phase pair is stable at lower temperatures and thus their continued presence may also be due to kinetic limitations on the conversion to ye'elimite and belite. Apart from improving the sulfur flow rate (e.g. by using a melt feeder), increasing the residence time and controlling the lime to silica and alumina ratio, the presence of $\mathrm{C} \$$ and $\mathrm{C}_{2} \mathrm{AS}$ phases may also be prevented by further optimising the kiln atmospheric conditions to increase the temperature driving force for ye'elimite formation (i.e. working closer to the lower sulfur dioxide partial pressure limit); however, kinetic limitations may also need to be considered.

Sieve analysis was carried out to assess the particle size distribution of the produced clinker. Gradation was carried out on a standard sieve tower having successive mesh sizes of 35,10 , $5,2 \cdot 36,1 \cdot 18,0 \cdot 6,0 \cdot 3$ and $0 \cdot 15 \mathrm{~mm}$. The clinker was sampled via the quartering method to avoid bias in the collection process. The results are shown in Table 9. Aside from the difference in gradation, a clear change in colour was also observed between different particle sizes (see Figure 5).

The formation of ferrite and ye'elimite solid solutions of iron and aluminium is well known (Idrissi et al., 2010; Touzo et al., 2013) and is dependent on the aluminium oxide/iron oxide (A/F) ratio of the raw meal. In the course of this study, the substitution of aluminium with iron was experimentally estimated by scanning electron microscopy with energy dispersive x-ray spectroscopy (SEM-EDX) analysis in the backscattered mode. The mixed produced clinker was ground to a Blaine fineness of $4000 \mathrm{~m}^{2} / \mathrm{kg}$ before being impregnated with resin and subsequently polished with increasingly fine grades of silicon carbide paper. Any remaining scratches were removed with a final diamond polish using a $0 \cdot 25 \mu \mathrm{m}$ abrasive prior to carbon coating the sample. Images were captured using a Carl Zeiss evoMA 10 operating at $15 \mathrm{keV}$ and a working distance of $10 \mathrm{~mm}$. Individual EDX points were captured with an $80 \mathrm{~mm}^{2}$ Oxford Instruments silicon drift detector. An overview of the produced clinker particles is shown in Figure 6(a). Clinker grains varied in size but typically averaged $50 \mu \mathrm{m}$, although some were in excess of $200 \mu \mathrm{m}$ in diameter. By eye, three distinct levels of greyscale can be distinguished at higher magnification: dark grey, light grey and white. EDX analysis confirmed that the brightest of the particles consisted of either titanium-rich or iron-rich clusters, indicative of either perovskite $\left(\mathrm{CaTiO}_{3}\right)$ or ferrite $\left(\mathrm{C}_{2}(\mathrm{~A}, \mathrm{~F})\right)$ or mixtures of the two. A sample EDX measurement of one of these titanium/iron-rich clusters yielded an atomic composition (by weight) of $62 \cdot 13 \% \mathrm{O}, 0.9 \% \mathrm{Mg}$, $6 \cdot 29 \% \mathrm{Al}, 0 \cdot 58 \% \mathrm{Si}, 1 \cdot 61 \% \mathrm{~S}, 0 \cdot 06 \% \mathrm{~K}, 18 \cdot 5 \% \mathrm{Ca}, 1 \cdot 14 \% \mathrm{Ti}$ 


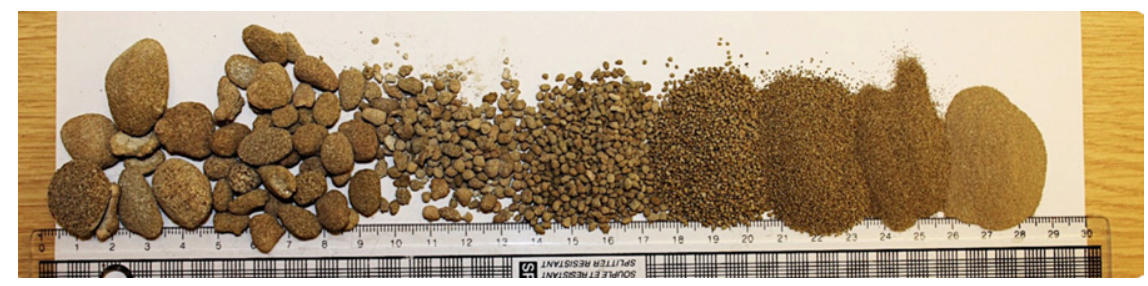

Figure 5. Visual representation of the particle size distribution of the produced clinker. The scale divisions on the rule are in centimetres

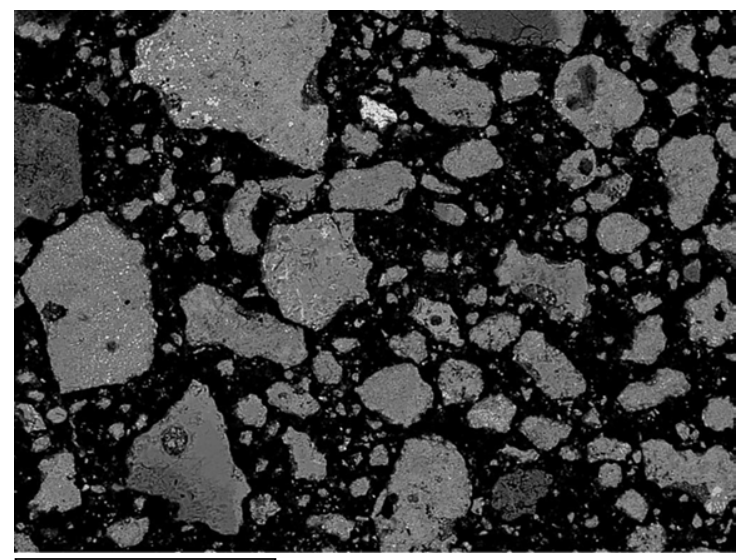

$200 \mu \mathrm{m}$

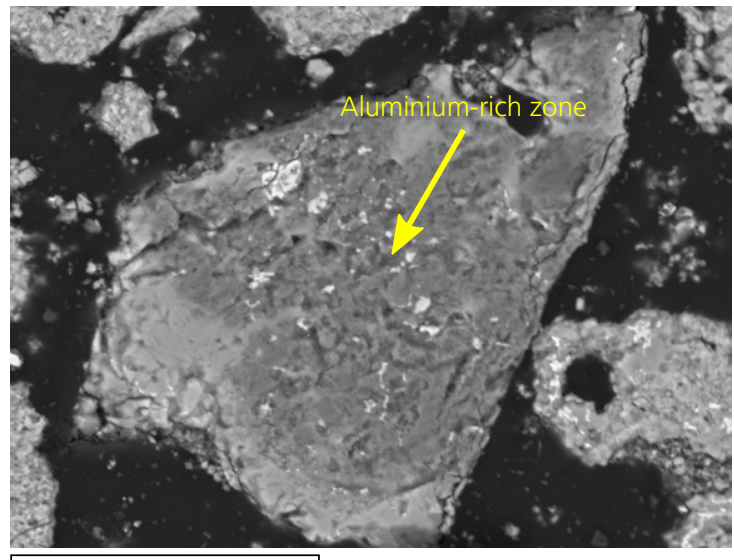

$40 \mu \mathrm{m}$

(b)

Figure 6. SEM observations of the produced clinker. (a) Overall image of several clinker grains where three main grey levels can be seen. The darkest zone (b) consists primarily of aluminium (a)

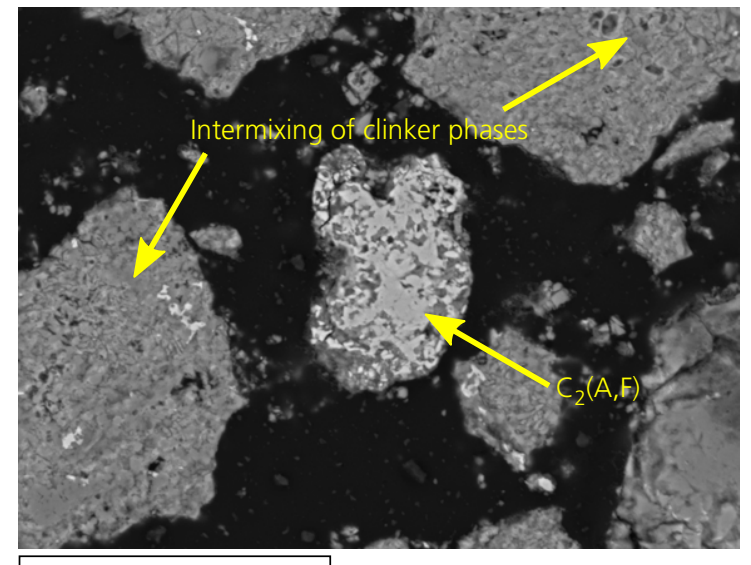

(c)

oxide whereas the light grey and white zones (c) make up for intermixed clinker phases $\left(C_{4} A_{3} \$, C_{2} S, C_{2} A S\right)$ and $C_{2}(A, F)$ respectively and $8.79 \% \mathrm{Fe}$; this shows that these 'brightest' clusters were rich in iron but also contained titanium.

EDX analyses of the darkest zones, for which a magnified region is shown in Figure 6(b), were carried out and the elemental compositions by weight are listed in Table 10 . The darkest zones were characterised as consisting primarily of aluminium, with traces of calcium and silicon, and their composition did not correspond to any of the expected clinker phases. However, the EDX measurements matched much more closely those obtained for bauxite (see Table 2), suggesting that some bauxite had only partially reacted during the clinkering process. This suggested, in 
Advances in Cement Research Volume 28 Issue 10
Production of belite calcium

sulfoaluminate cement using sulfur

as a fuel and as a source of clinker

sulfur trioxide: pilot kiln trial

Hanein, Galan, Elhoweris et al. turn, that the level of mixing may have been insufficient. However, no pure alumina phases were detected in the XRD pattern of the obtained clinker; this may be due to the scarcity of remaining bauxite. SEM observations showed only a handful of clinker grains containing the dark aluminium-rich regions. This scarcity can be gleaned further from Table 8; comparing the overall aluminium oxide content of the raw feed and that of the clinker back-calculated from quantitative XRD, $24.6 \%$ and $22.6 \%$ by weight respectively, all but $2 \%$ of the aluminium oxide is accounted for in the crystalline phases identified. As the bauxite is not pure, less than the nominal $2 \%$ likely remains in the clinker and is not identifiable in the XRD patterns.

\begin{tabular}{|c|c|c|}
\hline & $\begin{array}{c}\text { SEM } \\
\text { (average of } 36 \\
\text { measurements) }\end{array}$ & $\mathrm{XRF}$ \\
\hline Calcium & $1 \cdot 73 \pm 1 \cdot 73$ & 0.13 \\
\hline Aluminium & $44.92 \pm 4.94$ & $42 \cdot 60$ \\
\hline Silicon & $1 \cdot 61 \pm 1 \cdot 70$ & $6 \cdot 24$ \\
\hline Iron & $0 \cdot 34 \pm 0 \cdot 30$ & 0.98 \\
\hline Titanium & $0.58 \pm 0.75$ & $2 \cdot 37$ \\
\hline Magnesium & $0.02 \pm 0.10$ & 0.00 \\
\hline Potassium & $0.57 \pm 0.58$ & 0.44 \\
\hline Phosphorus & Not measured & 0.04 \\
\hline Oxygen & $50 \cdot 08 \pm 1 \cdot 59$ & $47 \cdot 19$ \\
\hline
\end{tabular}

Table 10. SEM-EDX analysis of the dark zones of the clinkers compared with XRF analysis of bauxite. The XRF values are normalised by the loss on ignition and broken into elemental components (Table 2)

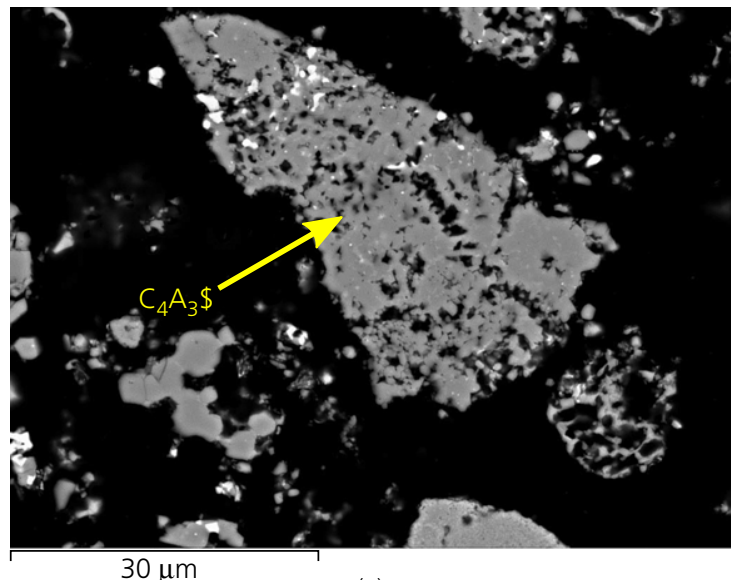

(a)

Figure 7. Ye'elimite grain (a) and ferrite (b) in the aluminium-rich clinker where $\mathrm{C}_{2} \mathrm{~S}$ has been removed by selective dissolution. The clinker particles appear porous where $\mathrm{C}_{2} \mathrm{~S}$ had likely formed. From
The white zones in Figure 6(c) depict a magnified clinker grain comprising primarily of ferrite and the light grey zones make up for intermixed clinker phases $\left(\mathrm{C}_{4} \mathrm{~A}_{3} \$, \mathrm{C}_{2} \mathrm{~S}, \mathrm{C}_{2} \mathrm{AS}\right)$. More often than not, the light grey zones show little variation in greyscale and it is nearly impossible to distinguish between $\mathrm{C}_{4} \mathrm{~A}_{3} \$, \mathrm{C}_{2} \mathrm{~S}, \mathrm{C} \$$ and $\mathrm{C}_{2} \mathrm{AS}$ using this technique. EDX analyses on various sites showed that such zones consisted primarily of calcium, aluminium, silicon and sulfur. To measure the iron content in ye'elimite and ferrite, belite was removed from the clinker by selective dissolution. In this procedure, $10 \mathrm{~g}$ of clinker (4000 $\mathrm{m}^{2} / \mathrm{kg}$ Blaine fineness) was extracted with $130 \mathrm{ml}$ of methanol and $60 \mathrm{~g}$ of salicylic acid for $1 \mathrm{~h}$ before filtering in a Buchner funnel. The filtrate was washed with methanol to remove any residual salicylic acid and dried at $60^{\circ} \mathrm{C}$ until the weight was constant. XRD analysis showed that the filtrate consisted of $\mathrm{C}_{4} \mathrm{~A}_{3} \$, \mathrm{C}_{2} \mathrm{AS}, \mathrm{C} \$, \mathrm{CT}$ and $\mathrm{C}_{2}(\mathrm{~A}, \mathrm{~F})$ and was free of $\mathrm{C}_{2} \mathrm{~S}$.

The ye'elimite and ferrite grains in the clinker stripped of belite are shown in Figures 7(a) and 7(b), respectively. The clinker grains themselves have a porous appearance, where the pores correspond mainly to dissolved belite. In this state, the solid solutions of ye'elimite and ferrite can be observed with greater ease. Ye'elimite has the general formula $\mathrm{C}_{4}\left(\mathrm{~A}_{3-x} \mathrm{~F}_{x}\right) \$$, where the principal solid solution is between aluminium and iron. SEM-EDX analysis on an average of 40 points showed a ratio of iron/aluminium of $0 \cdot 017 \pm 0.009$ and, solving for $x$, a more accurate composition in the clinker was found to be $\mathrm{C}_{4}\left(\mathrm{~A}_{2 \cdot 95} \mathrm{~F}_{0 \cdot 05}\right) \$$. Similarly, ferrite takes the form $\mathrm{C}_{2}\left(\mathrm{~A}_{y} \mathrm{~F}_{1-y}\right)$. On an average of 23 points, the aluminium/iron ratio was measured to be $0 \cdot 84 \pm 0 \cdot 16$, leading to the composition $\mathrm{C}_{2}\left(\mathrm{~A}_{0 \cdot 455} \mathrm{~F}_{0 \cdot 545}\right)$. This is quite different from the assumed composition of $\mathrm{C}_{6} \mathrm{~A}_{2} \mathrm{~F}$ used in the mix design calculations and helps to explain the deviation from the expected output composition.

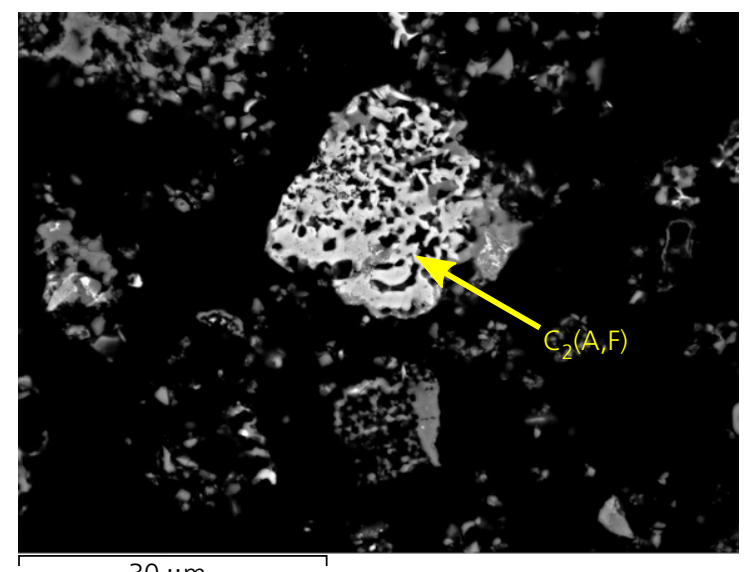

(b)

these grains, EDX analysis was made possible with greater confidence to measure the $\mathrm{A} / \mathrm{F}$ ratio in both clinker phases 
Thermodynamic data for $\mathrm{C}_{4} \mathrm{AF}$ exist in the database used (Hanein et al., 2015b); thus, assuming $\mathrm{C}_{4} \mathrm{AF}$ to be the ferrite phase formed and neglecting any iron substitution in ye'elimite (as it is minimal), the thermodynamic model was used to recalculate the phase compositions under the specified kiln operating conditions. The phase compositions were calculated to be (by weight) $7 \% \mathrm{C}_{4} \mathrm{AF}, 43 \% \mathrm{C}_{2} \mathrm{~S}, 43 \% \mathrm{C}_{4} \mathrm{~A}_{3} \$, 2 \% \mathrm{CT}$ and $5 \% \mathrm{C}_{5} \mathrm{~S}_{2} \$$ (note that the thermodynamic data of ternesite used were derived following the same procedure described by Hanein et al. (2015a)). Aside from the lack of gehlenite and anhydrite, these predictions are close to the achieved outputs, indicating the opportunities that thermodynamic calculations can provide in predicting cement clinker outputs.

Idrissi et al. (2010) observed iron substitution in ye'elimite to be of the form $\mathrm{C}_{4} \mathrm{~A}_{(3-x)} \mathrm{F}_{x} \$$, where $x$ ranges between 0 and $0 \cdot 75$, while Touzo et al. (2013) found $x$ to be between 0 and 0.34. Although Touzo et al. (2013) did not work at such high raw-meal $\mathrm{A} / \mathrm{F}$ ratios and their samples also partially melted, the $x$ value obtained in the current study $(\approx 0 \cdot 05)$ agrees with the trend shown by Touzo et al. (2013). On the other hand, for the ferrite solid solution $\left(\mathrm{C}_{2} \mathrm{~A}_{y} \mathrm{~F}_{1-y}\right)$, a value of $y \approx 0.455$ was obtained. Thus, even at the high $\mathrm{A} / \mathrm{F}$ ratios in the raw meal, the $\mathrm{A} / \mathrm{F}$ molar ratio in ferrite did not exceed 1 - this is contradictory to the work of Touzo et al. (2013) who showed an A/F molar ratio in ferrite as high as $\approx 1.2$ even at lower raw-meal $\mathrm{A} / \mathrm{F}$ ratios than those used in the current study. Apart from the difficulties of detecting ferrites in XRD analysis and the fact that the clinker produced in the current study was mainly sintered and did not form from the crystallisation of melt, these observations may explain why the expected ferrite content (in the target clinker) was not observed.

\section{Conclusions}

This work has demonstrated that the sequestration of sulfur from kiln combustion gas into clinker is feasible in a rotary kiln at temperatures in excess of $1200^{\circ} \mathrm{C}$. It has also been shown that all of the sulfur required for the formation of ye'elimitecontaining cement clinkers can be delivered via the combustion of sulfur-containing fuel. Adding sulfur in the form of solid calcium sulfate is also straightforward and it is likely that sulfur may be supplied from both fuel and from sulfates such as calcium sulfate. What is crucial is the role that vapour-solid equilibria plays during clinkering and this statement applies to clinkering Portland cement as well as various calcium sulfoaluminate cements. As has been shown, sulfur can be added to the batch by vapour-solid reactions but the reverse - the evolution of sulfur from solids - can also occur depending on the $\mathrm{SO}_{x}$ partial pressure. The balance of this has a role in controlling the clinkering of Portland cement, especially when sulfur-containing fuels are used, as well as in C\$A clinkering where sulfur that is not retained in the clinker may impose a burden on scrubbers or environmental emissions. Despite the short residence time and the fluctuating sulfur dioxide partial pressure in the clinkering zone of the kiln used in this work, the results demonstrate the successful use of sulfur as both a source of energy and a source of sulfur trioxide in clinker. Contradictory to published literature, it is shown that the $\mathrm{A} / \mathrm{F}$ molar ratio in the ferrite phase of sintered b-C\$A clinkers does not exceed 1, even at the high raw-meal $\mathrm{A} / \mathrm{F}$ ratio used here. It has also been shown that, at this $\mathrm{A} / \mathrm{F}$ ratio, iron substitution in ye'elimite is minimal $(<2 \mathrm{~mole} \%)$. The success of this trial also clearly demonstrates that applying computational thermodynamics to design and formulation can significantly enhance process development.

\section{Future work}

A novel b-C\$A process technology has been validated for application at larger scale. Future developments will focus on integrating a sulfur dioxide scrubbing system with the cyclone preheaters and the use of a more efficient kiln to realise expected fuel savings through the combustion of sulfur. Publication of a second part of this study, which focuses on the hydration and mechanical properties of the clinkers, is underway. To achieve a higher degree of control of the kiln atmosphere, a more appropriate method to feed sulfur, such as a liquid burner, is also recommended. Future work will also assess the formulation of a higher iron content clinker as this could prove a route to reducing production costs.

\section{Acknowledgements}

The authors gratefully acknowledge the financial support provided by the Gulf Organization for Research and Development (GORD), Qatar, through research grant number ENG016RGG11757. The authors would also like to acknowledge Thomas Matschei and Guanshu Li for the stimulating and fruitful discussions concerning the development of this work. The continuous support prior to, during and after the pilot kiln trial from Vadym Kuznietsov and the entire team at IBU-tec is also greatly appreciated.

\section{REFERENCES}

Alvarez-Pinazzo G, Cuesta A, Garcia-Mate M et al. (2012) Rietveld quantitative phase analysis of yeelimite containing cements. Cement and Concrete Research 42(7): 960-971.

BSI (2013) BS EN 196-2:2013: Method of producing cement Part 2: Chemical analysis of cement. BSI, London, UK.

Chen I and Juenger M (2011) Synthesis and hydration of calcium sulfoaluminate-belite cements with varied phase compositions. Journal of Materials Science 46(8): $2568-2577$.

Colville AA and Geller S (1971) The crystal structure of brownmillerite, $\mathrm{Ca}_{2} \mathrm{FeAlO}_{5}$. Acta Crystallographica B. Structural Crystallography and Crystal Chemistry 27(12): 2311-2315.

Cuesta AA, De la Torre AG, Losilla ER et al. (2013) Structure, atomistic simulations, and phase transition of stoichiometric yeelimite. Chemistry of Materials 25(9): 1680-1687.

Cuesta AA, De la Torre AG, Losilla ER, Santacruz I and Aranda MAG (2014) Pseudocubic crystal structure and 
phase transition in doped ye'elimite. Crystal Growth \& Design 14(10): 5158-5163.

Dollase WA (1986) Correction of intensities for preferred orientation in powder diffractometry: application of the March model. Journal of Applied Crystallography 19(4): 267-272.

Finger LW, Cox DE and Jephcoat AP (1994) A correction for powder diffraction peak asymmetry due to axial divergence. Journal of Applied Crystallography 27(6): 892-900.

Galan I, Glasser FP, Elhoweris A, Tully S and Murdoch A (2014) Novel process for calcium sulfoaluminate cement production. Proceedings of the 34th Cement and Concrete Science Conference, Sheffield, UK.

Gartner EM (2004) Industrially interesting approaches to 'low- $\mathrm{CO}_{2}$ ' cements. Cement and Concrete Research 34(9): 1489-1498.

Hanein T, Elhoweris A, Galan I, Glasser FP and Bannerman MN (2015a) Thermodynamic data of ye'elimite $\left(\mathrm{C}_{4} \mathrm{~A}_{3} \$\right)$ for cement clinker equilibrium calculations. In Proceedings of the 35th Cement and Concrete Science Conference, Aberdeen, UK (Imbabi M and Glasser FP (eds)). Centre for Innovative Building Materials and Technologies, Aberdeen, UK.

Hanein T, Glasser FP and Bannerman MN (2015b)

Thermodynamics of Portland cement clinkering. In Proceedings of the 14th International Congress on the Chemistry of Cement, Beijing, China (Shi C and Yao Y (eds)). China building materials academy, Beijing, China.

Hanein T, Imbabi MS, Glasser FP and Bannerman MN (2016) Lowering the carbon footprint and energy consumption of cement production: a novel calcium sulfoaluminate cement production process. In Proceedings of the 1st International Conference on Grand Challenges in Construction Materials, Los Angeles, CA, USA (De Fillipo J and Sant G (eds)). University of California, Los Angeles, CA, USA, pp. 1-5.

Hasanbeigi A, Price L and Lin E (2012) Emerging energy-efficiency and $\mathrm{CO}_{2}$ emission-reduction technologies for cement and concrete production: a technical review. Renewable and Sustainable Energy Reviews 16(8): 6220-6238.

Idrissi M, Diouri A, Damidot D et al. (2010) Characterisation of iron inclusion during the formation of calcium sulfoaluminate phase. Cement and Concrete Research 40(8): 1314-1319.

Imbabi MS, Glasser FP and Galan I (2014) A Method for Producing Cement. Gulf Organisation for Research and Development, Doha, Qatar, WO2014/177858A8.
Irran E, Tillmanns E and Hentschel G (1997) Ternesite $\mathrm{Ca}_{5}\left(\mathrm{SiO}_{4}\right)_{2} \mathrm{SO}_{4}$, a new mineral from the Ettringer Bellerberg/Eifel, Germany. Mineralogy and Petrology 60(1-2): 121-132.

Juenger MCG, Winnefeld F, Provis JL and Ideker JH (2011) Advances in alternative cementitious binders. Cement and Concrete Research 41(12): 1232-1243.

Kirfel A and Will G (1980) Charge density in anhydrite, $\mathrm{CaSO}_{4}$, from x-ray and neutron diffraction measurements. Acta Crystallographica B: Structural Crystallography and Crystal Chemistry 36(12): 2881-2890.

Larson AC and Von Dreele RB (2004) General Structure Analysis System (GSAS) LAUR. Los Alamos National Laboratory, Los Alamos, NM, USA.

Li GS, Walenta G and Gartner EM (2007) Formation and hydration of low- $\mathrm{CO}_{2}$ cements based on belite, calcium sulfoaluminate and calcium aluminoferrite In Proceedings of the 12th International Congress on the Chemistry of Cement in Montreal, QC, Canada (Beaudoin JJ, Makar JM and Raki L (eds)). Cement Association of Canada, Institute for Research in Construction, Ottawa, ON, Canada.

Louisnathan SJ (1971) Refinement of the crystal structure of a natural gehlenite, $\mathrm{Ca}_{2} \mathrm{Al}(\mathrm{Al}, \mathrm{Si})_{2} \mathrm{O}_{7}$. The Canadian Mineralogist 10: 822-837.

Mumme WG, Hill RJ, Bushnell-Wye G and Segnit ER (1995) Rietveld crystal structure refinements, crystal chemistry and calculated powder diffraction data for the polymorphs of dicalcium silicate and related phases. Journal of Mineralogy and Geochemistry 169(1): 35-68.

Peray KE and Waddell JJ (1986) The Rotary Cement Kiln. Chemical Publishing Company, London, UK.

Sasaki S, Prewitt CT, Bass JD and Schulze WA (1987) Orthorhombic perovskite $\mathrm{CaTiO}_{3}$ and $\mathrm{CdTiO}_{3}$ : structure and space group. Acta Crystallographica C: Crystal Structure Communications 43(9): 1668-1674.

Strigac J and Majling J (1997) Phase composition development of calcium sulphoaluminate belite cement in the $\mathrm{SO}_{x}$ atmosphere. World Cement 28(1): 97-98.

Thompson P, Cox DE and Hastings JB (1987) Rietveld refinement of Debye-Scherrer synchrotron x-ray data from $\mathrm{Al}_{2} \mathrm{O}_{3}$. Journal of Applied Crystallography 20(2): 79-83.

Touzo B, Scrivener KL and Glasser FP (2013) Phase compositions and equilibria in the $\mathrm{CaO}-\mathrm{Al}_{2} \mathrm{O}_{3}-\mathrm{Fe}_{2} \mathrm{O}_{3}-\mathrm{SO}_{3}$ system, for assemblages containing ye'elimite and ferrite $\mathrm{Ca}_{2}(\mathrm{Al}, \mathrm{Fe}) \mathrm{O}_{5}$. Cement and Concrete Research 54: 77-86. 